\title{
The Possible Ameliorative Effect Of Dimethyl Dicarboxylate Biphenyl (DDB) Against Mancozeb-Induced Testicular Toxicity In Rats
}

\author{
Manar Effat Selim \\ Zoology Department, Faculty of Science, Ain Shams University
}

\begin{abstract}
Mancozeb, an organocarbamate fungicide, has been widely used for several decades. Despite the wide scope of exposure to this compound, up till now, there is a scarcity in published studies on the toxicity of mancozeb and its impacts on cell structure and functions. Thus the present study was designed to investigate the possible counteracting effect of dimethyl dicarboxylate biphenyl (DDB) in reducing the hazards caused by mancozeb in the testies. The effects of mancozeb given separately or simultaneously with DDB on rat testis were studied histologically and ultra structurally. Twenty-one male albino rats were divided into three groups, 7 rats each. The first group was given orally $0.5 \mathrm{ml}$ of distilled water and served as control. Animals of the second group were given mancozeb orally at a dose level of $500 \mathrm{mg} / \mathrm{kg}$ b.wt for 15 consecutive days. Animals of the third group received the same dose of mancozeb as in the second group and simultaneously given DDB $(50 \mathrm{mg} / \mathrm{kg}$ b.wt $)$ through the same route of administration. Mancozeb treatment induced cellular damage manifested as exfoliation and destruction of the spermatogenic lineage. Destructed spermatids and Leydig cells were also pronounced. The ultra structural observations revealed marked cytoplasmic vacuolation in Sertoli cells and spermatogonia. Some cytoplasmic organelles of the spermatogonia and primary spermatocytes were degenerated. Moreover, destructed spermatids were pronounced in most of the seminiferous tubules. The interstitial cells appeared devoid of lipid droplets and the mitochondria appeared with disintegrated cristae.

Administration of DDB simultaneously with mancozeb ameliorated most of the testicular tissue damage. This was reflected as restoration of the normal appearance of the spermatogenic lineage. Numerous spermatids were demonstrated in the lumens of the seminiferous tubules, most of them showed similar structure to those of the control group. In conclusion, it is possible to suggest that DDB might have ameliorated and amended the abnormalities caused by mancozeb.
\end{abstract}

\section{Introduction}

Mancozeb, an organocarbamate fungicide, has been widely used for several decades. Nevertheless, up till now, the hazards caused by this fungicide on the cell structure and function have not been completely investigated. It is expected that a large number of people are potentially exposed to this fungicide including workers engaged in the production and use of this compound, people living in agricultural areas where the compound is sprayed and those consuming polluted products. 
Accordingly, experimental studies on probable hazardous effects of mancozeb, with the light and electron microscope should be considered to throw more light on the possible effects of marcozeb on cell biology.

Fejes et al., (2002) reported that dithane M-40, a fungicide formulated of 80\% mancozeb and copper sulphate caused embryomortality. They also added that light microscopic findings revealed degenerative changes in liver tissue with an increase in the activities of liver enzymes GPT and GOT. Studies have shown that mancozeb may cause an increase in incidences of malignant tumors, such as ear duct carcinoma, hepatocarcinomas, malignant tumors of Pancreas and thyroid gland, osteosarcomas of the head bones and hemolymphoreticular neoplasias (Belpoggi et al., 2002). Varnagy et al., (2001) studied the reproduction toxicity of dithane M-45, a fungicide formulated of $80 \%$ mancozeb and lead acetate. They found that the body weight of females diminished significantly before the pregnancy period, a similar body weight loss was also observed in males? Bindali and Kaliwal (2002) revealed that there was a complete inhibition of implantation in mice treated with $36 \mathrm{mg} / \mathrm{kg}$ b.wt mancozeb with a $100 \%$ Preimplantation loss. But there was a partial implantation in mice treated with 24 and 30 $\mathrm{mg} / \mathrm{kg}$ b.wt with 53.44 and $90.16 \%$ Preimplantation loss respectively. However, implantation was not affected in the 18 $\mathrm{mg} / \mathrm{kg}$ mancozeb-treated mice with a $4.92 \%$ Pre-implantation loss when compared to oil-treated controls. Baligar and Kaliwal (2001) reported that the histological examination of the ovary revealed the presence of less number of Corpora lutea with reduced ovary size in mancozebtreated rats in comparison with the corresponding controls. Mancozeb also caused a significant decrease in the uterus and ovary levels of glycogen, protein, total lipids and Phospholipids in rats treated with
$600 \mathrm{mg} / \mathrm{kg} /$ day whereas, there was an increased decrease in those parameters with $700 \mathrm{mg} / \mathrm{kg} /$ day.

Tomasi et al., (2001) studied the effect of mancozeb on thyroid function, metabolic rate and thermoregulation in cotton rats. They found a decrease in the thyroid hormone concentrations concomitant with a generally compensatory increase in thyroxine turnover. Mancozeb was also reported to produce significant enzymatic changes associated with pathomorphological changes in liver, brain and kidney with loss in body weight in male rats at doses 500, 1000 and 1500 $\mathrm{mg} / \mathrm{kg} /$ day (Kackar et al., 1999).

Dimethyl dicarboxylate biphenyl (DDB) is a synthetic drug mimics the Schizandarin $\mathrm{C}$, one of the components isolated from Fructus schizandrae. It is used in China as a curative agent for patients with acute and chronic viral hepatitis or an adjunct agent for patients under cancer chemotherapy (Liu et al., 1992; Liu et al., 1995; Kim et al., 2000; Oh et al., 2000). DDB slows down the hepatic degradation of testos-terone through formation of cytochrome $\mathrm{P}_{450}$ complex (Kim et al., 2000; Ji-Yeon et al., 2001 and Back et al., 2001). Indoki et al., (2004) stated that $\mathrm{DDB}$ is a heterodimer of $\mathrm{DDB}_{1}$ and $\mathrm{DDB}_{2}$ which is implicated in the repair of UVinduced DNA damage. Weiliu et al., (2000); Ann et al., (2000) and Mitsuo et al., (2001) also added that DDB can rapidly translocate to the damaged DNA sites in some disorders like sun sensitivity, pigmentation abnormalities and high incidence of skin cancer.

Based on the aforementioned studies which demonstrated that DDB exerts a remarkable effect in maintaining and repairing tissue damage induced by xenobiotics, infections and irradiation, it is possible to assume that DDB might counteract or abate the deleterious effects of mancozeb. Consequently, the aim of this work was to investigate the probable 


\section{Manar Effat Selim}

protective effect of DDB on mancozeb induced injury in the testicular tissue of male rats.

\section{Material And Methods}

Mancozeb dithiocarbamate is a white powder with solubility $6 \mathrm{mg} / \mathrm{ml}$ in water and a molecular weight of 266.31 . Mancozeb was synthesized and supplied by Wady El-Nil Company. A dose of 500 $\mathrm{mg} / \mathrm{kg}$ b.wt. was used as prescribed by Kackar et al., (1999).

Male albino rats, with body weights ranging from 150 to $200 \mathrm{~g}$ were chosen for this study. Rodent commercial pellets and tap water were provided ad libitum. The rats were divided into 3 groups, each of 7 animals. The first group was given orally $0.5 \mathrm{ml}$ of distilled water and served as control. The second group was given mancozeb orally at a dose level of 500 $\mathrm{mg} / \mathrm{kg}$ for 15 days. The third group was given mancozeb as in group 2 simultaneously with an oral dose (50 $\mathrm{mg} / \mathrm{Kg}$ b.wt) of dimethyl dicarboxylate biphenyl (DDB) dissolved in distilled water for 15 days (Kim et al., 2000). The evaluation of DDB effect on the tissues was not among the objective scope of this investigation as its beneficial effect in maintaining proper tissue structure have been repeatedly documented (Back et al., 2001; Weiliu et al., 2000 and Mitsuo et al., 2001). So, the study has focused on the possible remedial potentials of DDB on mancozeb-induced Perturbation in the testicular tissue that has not been previously investigated.

The treated and control rats were sacrified $24 \mathrm{hrs}$ after the last drug administration and small pieces from definite parts of the testicular tissues were immediately transferred to the appropriate fixatives. For electron microscopic studies, small pieces of testis were fixed in buffered $3 \%$ glutaraldehyde for $2 \mathrm{hrs}$ and post fixed in $1 \%$ osmium tetroxide. Fixed specimens were dehydrated in ethanol and embedded in Epon. One micron thick sections were cut, stained with touluidine blue and examined by the light microscope. Ultrathin sections were stained with uranyl acetate and lead citrate and examined with a Joel 1200 EX 11 Transmission Electron Microscope, at the EM Unit of the Faculty of Science, Ain Shams University.

\section{Results}

In the present study, the normal testis of rat is enclosed by a fibrous connective tissue layer, the tunica albuginea, and consists of a large number of seminiferous tubules separated by intertubular or interstitial tissue. Various stages of spermatogenesis are demonstrated. The spermatogenic epithelium is formed of spermatogonia, primary and secondary spermatocytes, spermatids and mature spermatozoa (Fig. 1). Sertoli cells are occasionally found between the spermatogonia adjacent to the basement membrane. Leydig cells are located in the intertubular connective tissue (Fig. 1).

Concerning the ultrastructural examination of the testis, the seminiferous tubules are lined by spermatogenic and supporting Sertoli cells (Fig. 2). The latter exhibit triangular or ovoid nuclei with deep indentation (Fig. 2). The intertubular space is occupied by blood vessels, nerves and interstitial cells of Leydig. The cytoplasm of such cells contains lipid droplets, mitochondira and smooth endoplasmic reticulum.

\section{Mancozeb-treated rats:}

Following mancozeb treatment, different types of cellular damage are detectable; no recognizable germinal elements appeared other than Sertoli cells and very few spermatogonia. The primary spermatocytes were detached from one 
another with destructed cytoplasm and tend to exfoliate (Figs. 3 \& 4). Destructed spermatids with Karyolytic nuclei were observed in almost all the tubules. The late spermatids seem to be dead in most of the testis treated with mancozeb and Sertoli cells were detected near the boundary tissue (Figs. 3 \& 4).

The ultrastructural examination of the testis revealed obvious alterations. The cytoplasm of Sertoli cells showed marked damage, indicated by cytoplamic vacuolation, most of the mitochondira revealed ill defined cristae and nuclei with irregular nuclear membrane (Fig. 5). The cytoplasmic organelles of the spermatogonia were severely destructed and cytoplasmic vacuolation was also pronounced (Figs. $6 \&$ 7). The cytoplasm of the primary spermatocytes appeared to be distorted. Mitochondrial cristae appeared with high electron density and the nuclear membrane was not distinguished (Fig. 8). Moreover, destructed spermatids in most of the seminferous tubules were clearly pronounced and the residual bodies appeared highly vacuolated (Fig. 9). Distortion of the interstitial cells was represented in the cytoplsmic inclusions, as most of the mitochondrial cristae were destructed, and no lipid components. The nucleus appeared with deep indentation (Fig. 10).

\section{Mancozeb and DDB-treated rats:}

Most of the seminiferous tubules of the testes of the animals given yellow seed and mancozeb exhibited a rather normal appearance (Figs.11\&12). However, tubules with intact spermatogenic epithel-ium were observed with slight rounded vacuoles but contained all types of germinal epithelial cells (Figs. $11 \& 12$ ). The interstitial cells manifested normal appearance with lipid droplets (Fig.11). At the ultrastructural level, the cytoplasmic contents of the Sertoli cells and spermatogonia appeared normal except minimal vacuolation of the cytoplasm of some cells (Figs. 13 \& 14). The mitochondria of the spermatogonia could be detected near the Golgi apparatus (Figs. $14 \& 15$ ). The nucleus appeared with loose chromatin structure (Fig. 14). The cytoplasm of the primary spermatocytes appeared normal with detected normal mitochondira (Fig. 16). The final products of meotic division are the late spermatids and spermatozoa. The early spermatids have a medium-sized pale with, round or oval nuclei (Fig. 17). The cytoplasm contains Golgi complex that produces several osmophilc carbohydrate-containing proacrosomal granules where some of them fuse to form the acrosomal granule that comes to rest on spermatid nucleus (Fig. 18). The early spermatids begin to elongate to the end process of spermatogenesis to give late spermatids (Figs. $19 \& 20 \& 21$ ). In the cytoplasm of Leydig cells, accumulated lipid droplets, mitochondrial condensation and a proliferated smooth endoplasmic reticulum were recognized (Fig. 22). Moreover, the nuclei of interstitial cells of Leydig markedly resuming their normal appearance (Fig. 22).

\section{Explanation Of Figures}

Fig. 1: Photomicrograph of a part of T.s of normal testis showing different stages of spermatogenesis and interstitial cells (Leydig cells) (In). Note, Sertoli cells (Se), Spermato-gonia (Spg), primary spermato-cytes (1 Sp), secondary spermatocytes (2 Sp), sperma-tids (S) and spermatozoa (SpZ). Toluidine blue $\times 1200$

Fig. 2: Electron micrograph of a part of T.S. of normal testicular tissue showing basal lamina (BL), Sertoli cells (Se), sper-matogonia (Spg), and primary spermatocytes (1 Sp). Note interstitial or Leydig cells (In). 
Figs. 3 \& 4: Photomicrographs of T.S. of testis of mancozeb- treated rats:-

Fig. 3: Showing destructed spermatogonia (Spg) with deteroriated cytoplasm, primary spermatocytes (1 $\mathrm{Sp})$ with obscured cytoplasm and clumped chromatin material. Note Karyolytic nuclei of spermatids (S) leaving empty spaces (arrows).

Fig.4:Showing another part of seminiferous tubules with degenerated spermatids (S) and exfoliated primary spermatoc-ytes (1 Sp) (arrows). Notice Sertoli cell nuclei (Se) near the boundary tissue. T.B. $\times 1200$.

Figs. 5 - 10: Electron micrographs of T.S. of testis of mancozeb-treated rats:-

Fig. 5: Revealing destructed vacuolated cytoplasm of Sertoli cells (arrows)

Fig. 6: Showing corrugated basal lamina (BL), cytoplamsic vacuolation (V) of Spermatogonia (Spg). Note mitoch-ondria (M) with destructed vesicles.

Fig. 7: A magnified part of Fig. 6 showing destructed Golgi $(\mathrm{G})$ and ruptured inner \& outer membranes of mitochondria and so their cristae.

Fig. 8: Revealing deteriorated cytoplasm of primary spermaocytes (1 Sp) and the nucleus (N) with ill-defined membrane. Note the electron dense mitrochondira (arrows).
Fig. 9: Showing residual bodies of late spermatids. Notice vacuolated cytoplasm (V) and destructed mitochondria (M).

Fig. 10: Revealing atrophied interstitial cells or Leydig (In). Notice the aggregation of mitochondira (M), absence of lipid droplets and the nucleus $(\mathrm{N})$ with folded membrane.

Figs. $11 \&$ 12: Photomicrographs of T.S. of parts of testis of mancozeb and DDB-treated rats showing normal appeara-nce of spermatogenic and spermi-ogenic lineage. Notice the numerous spermatids (S), the spermatozoa (SpZ) and the normal interstitial cells (In). T.B. 1200x

Figs. 13 - 21: Electron micrographs of T.S. of mancozeb and DDBtreated rats:-

Fig. 13: Showing sertoli cell with cytopl-asmic vacuolation (V). Note normal spermatogonia (Spg) and attached primary spermatocytes (1 Sp).

Fig. 14: Revealing spermatogonium (Spg) with its characteristic oval nucleus and fine granular nucleoplasm with chromatin material. Notice the cytoplasm containing spherical to ovoid mitochondia (M).

Fig. 15: A magnified part of Fig. 14 showing Golgi apparatus (G) and mitochondria (M). 
Fig. 16: Showing normal spermatocytes (1 Sp) and spermatids (S).

Fig. 17: Showing early spermatids (S) with acrosomal vacuole (arrow) and acrosomal granule (arrow head).

Fig. 18: A magnified part of Fig. 17 showing prominent Golgi complex (G) consisting of Parallel lamellae and some vesicles.

Figs. 19 \& 20: Showing late spermatids toward the end of f spermiogenesis (arrows).

Fig. 21: Showing section of tails (arrows) and middle pieces (arrow head) of late spermatids in the lumen of the semin-iferous tubules.

Fig. 22: Revealing normal interstitial cells. Note, the cytoplasm containing mumerous lipid droplets (L) with different shapes of mitochondira (M) and a prolific system of smooth endoplasmic reticulum (SER).
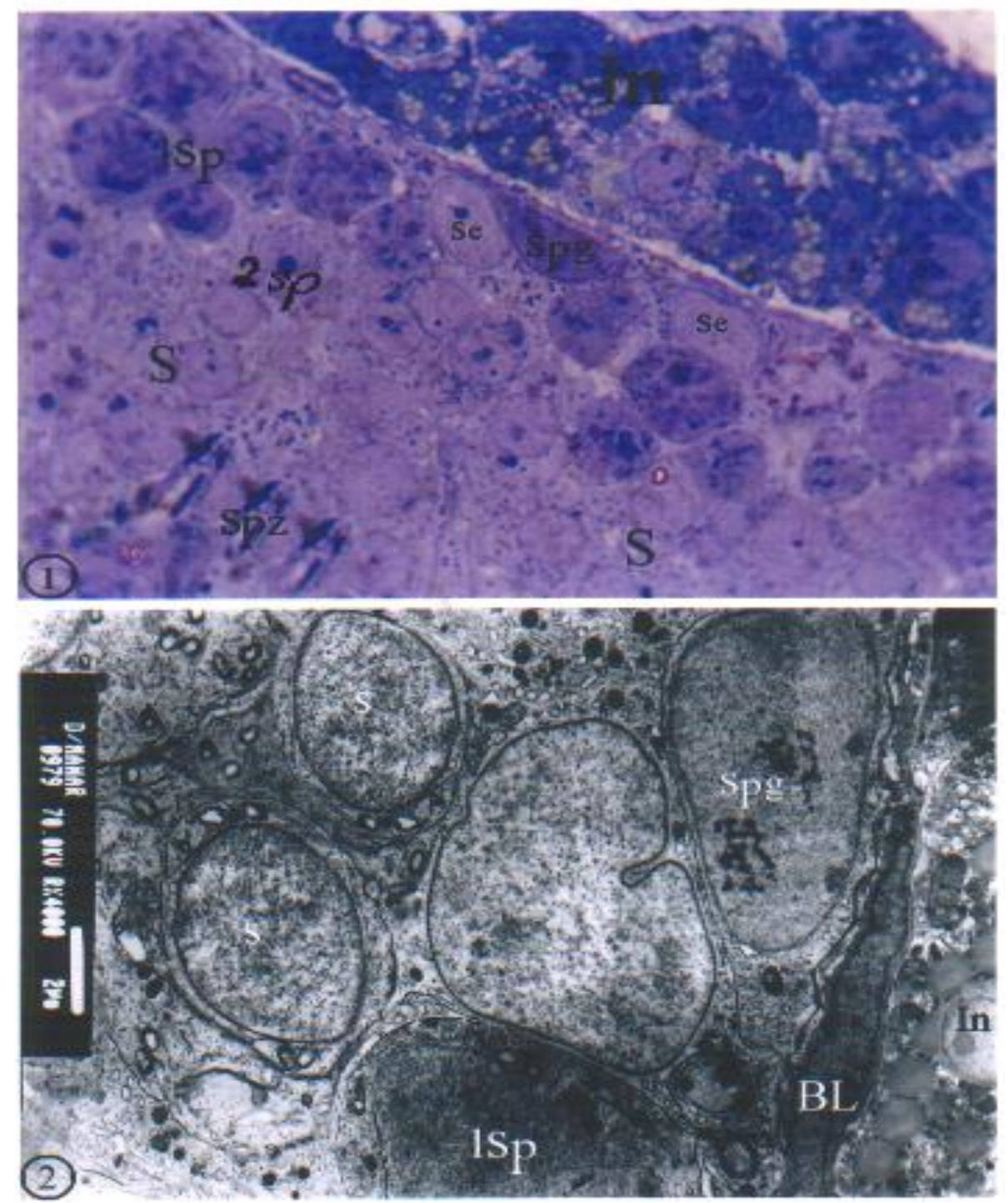

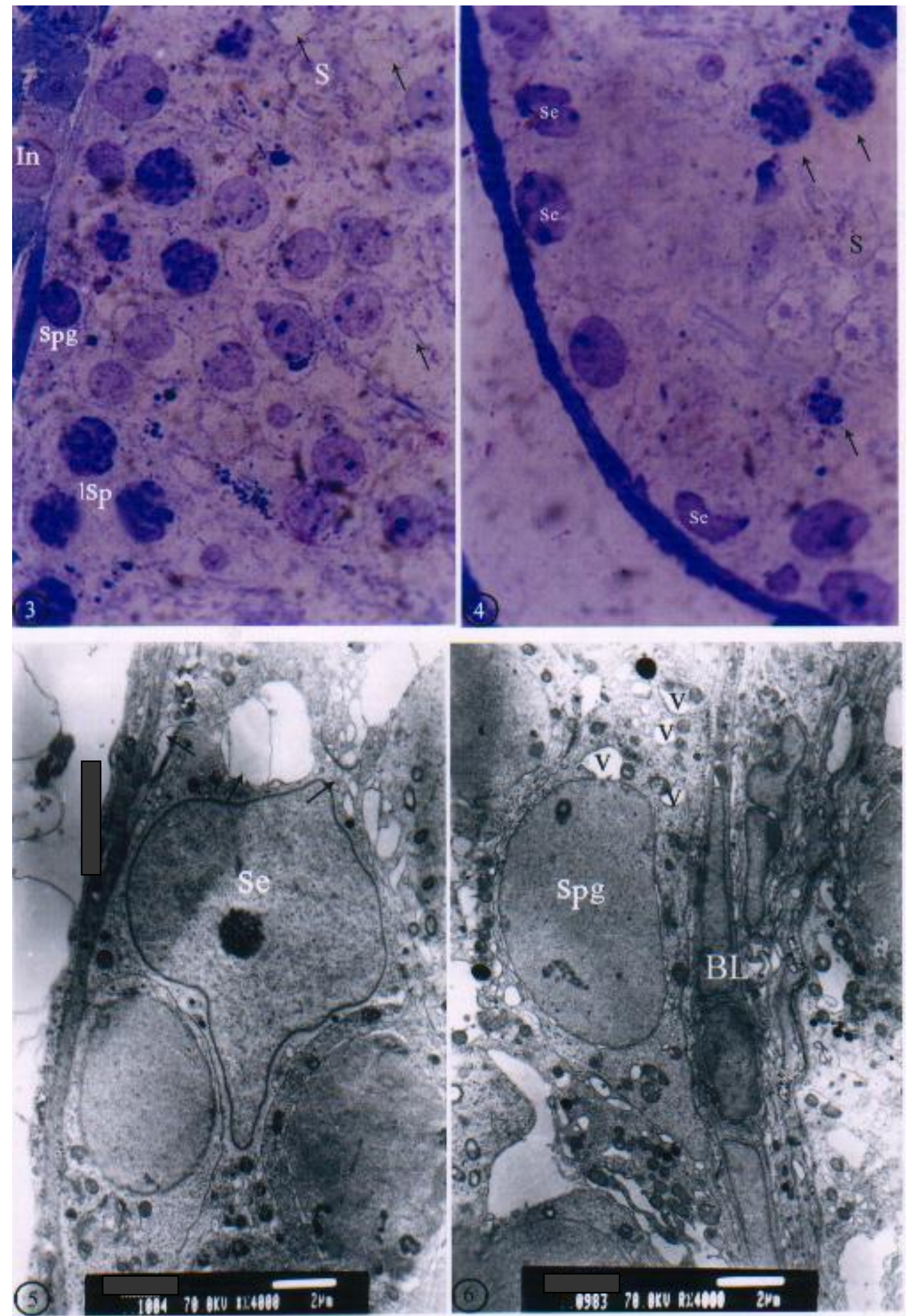
The Possible Ameliorative Effect Of Dimethyl........

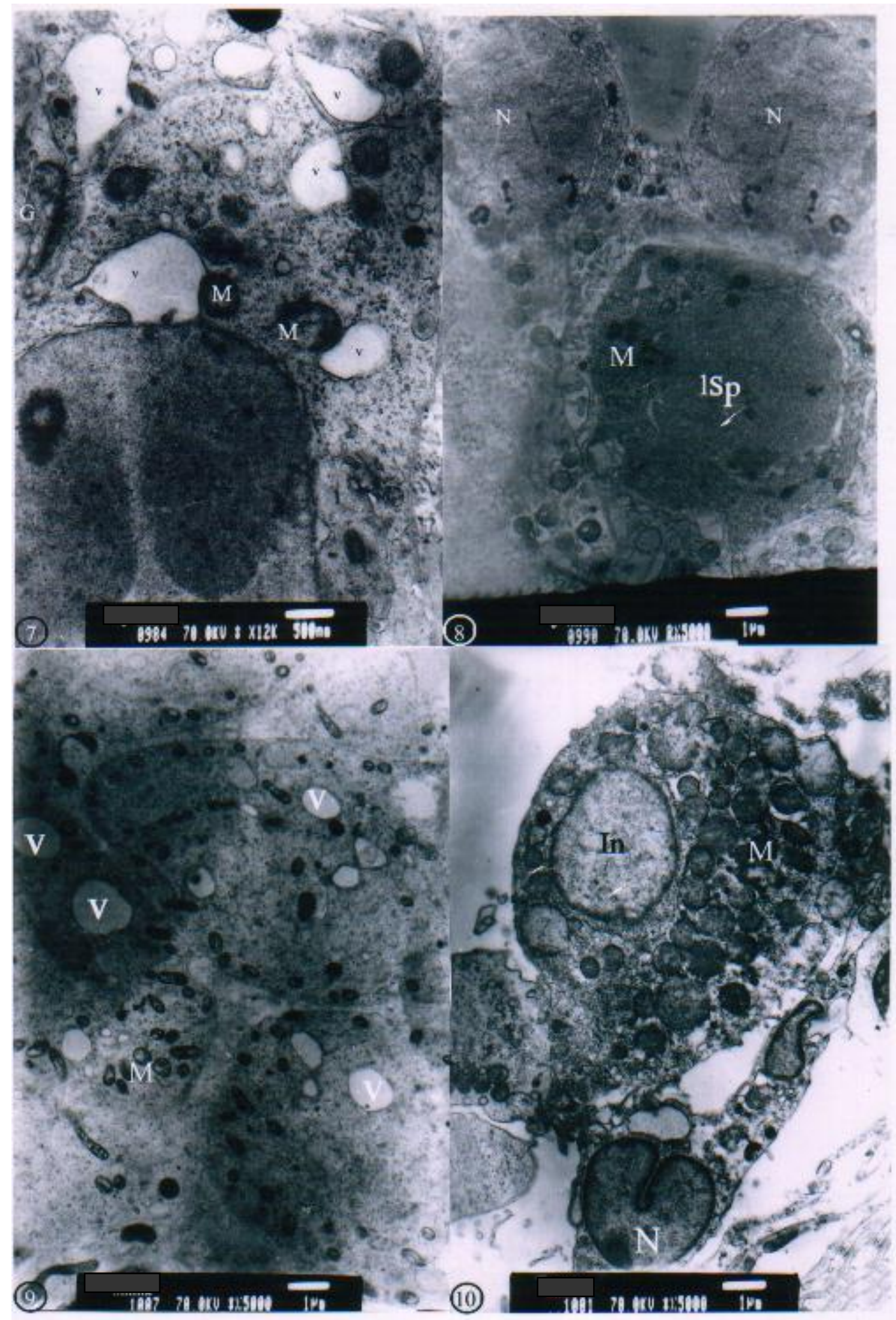



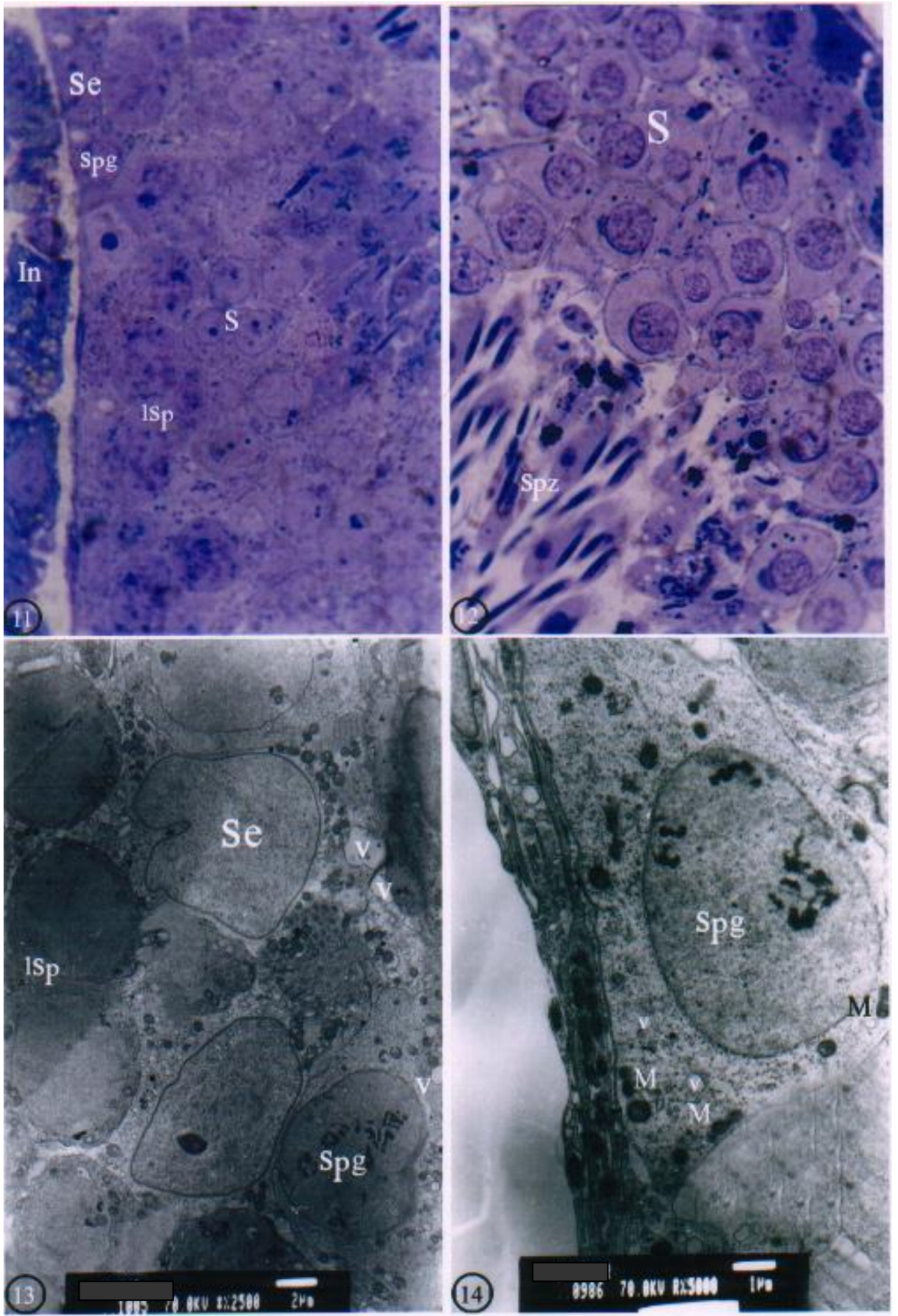
The Possible Ameliorative Effect Of Dimethyl........

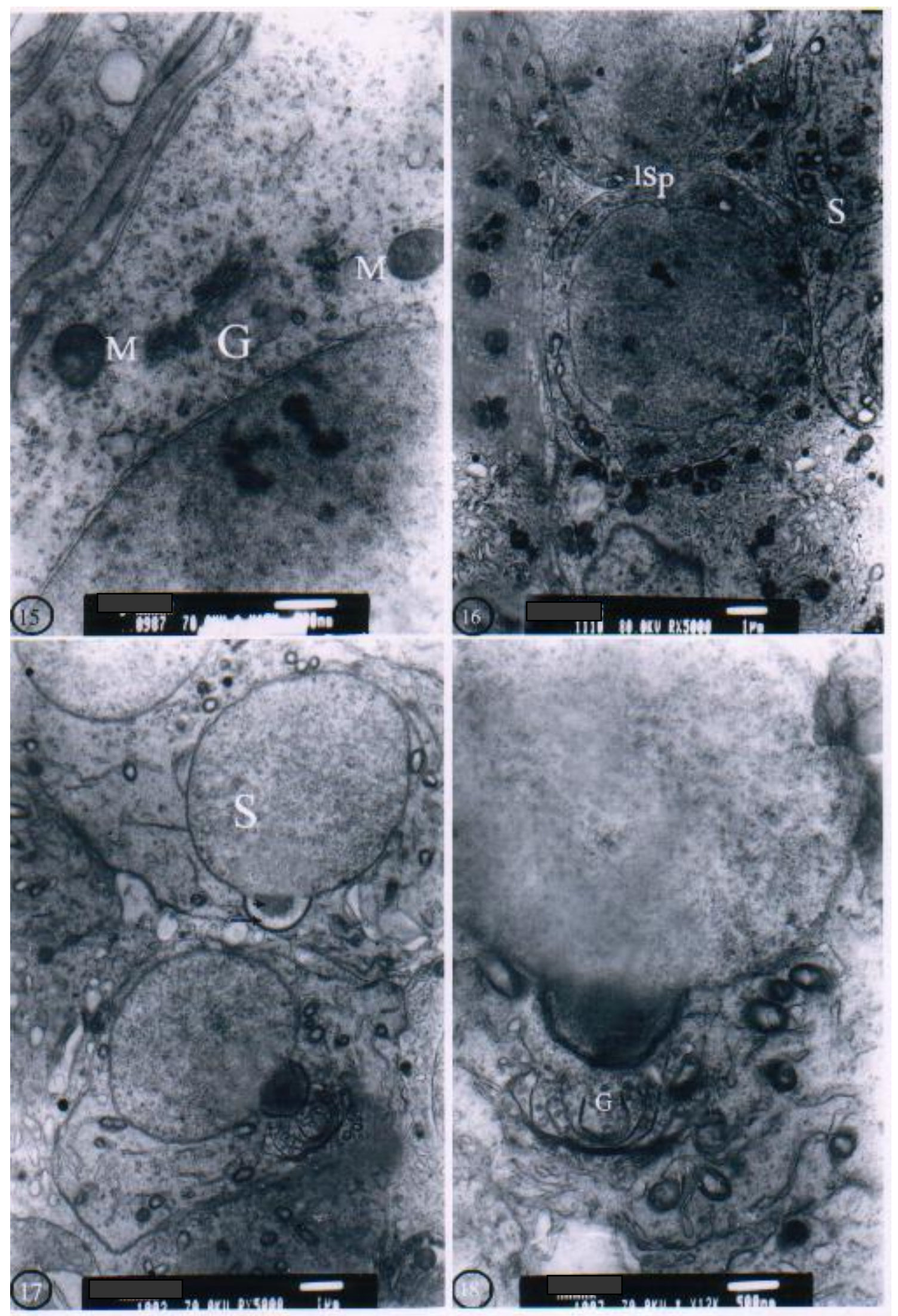


Manar Effat Selim 


\section{Discussion}

The present study showed that the administration of mancozeb $(500 \mathrm{mg} / \mathrm{kg}$ b.wt) daily for 15 days caused cytoplasmic changes including intracellular vacuolation, degeneration of some cytoplasmic organelles and nuclear disorders. Belpoggi et al., (2002) revealed the presence of mancozeb-induced alterations and malignant tumors in the mammary gland, ear duct, liver, panc-reas and thyroid gland. On that basis, the authors considered mancozeb as a multipo-tent carcinogenic agent. Histological studies on the reproduction toxicity of lead acetate and $80 \%$ mancozeb have shown a general tubulonephrosis of offsprings (Varnagy et al., 2001). Bindali and Kaliwal (2002) revealed that inhibition of implantation in mice by mancozeb may be due to its toxic effect concomitant with hormonal imbalance.

A similar interpretation was put forward by Baligar and Kaliwal (2001) after mancozeb administration into rats. They noticed that the size of the ovary was reduced, although there was a significant increase in the thyroid weight in all mancozeb-treated rats. Kackar et al., (1999) reported that the chronic exposure to mancozeb produced significant toxicological and pathological changes in rats that could be due to its poisoning effects.

In the present investigation, cytoplasmic vacuolation and exfoliation of germ cells were observed. Such vacuolation and exfoliation might be a sign of testicular toxicity and cell degeneration. According to Creasy and Foster (1991), premature exfoliation or sloughing of germ cells is a frequent finding in testicular toxicity. These authors suggested that the release of displaced germ cells was presumbly due to loss of the tenuous contact between Sertoli and germ cells.

In the present work, necrosis, degeneration and loss of germ cells were the most frequent manifestations of testicular injury. Even the supporting Sertoli cells were detected near the boundary tissue, which is known for its ability to survive xenobiotic insults. Thus, these findings confirm the reports of Creasy and Foster (1991), Gartner and Hiatt (1997) and Junqueira et al., (1998) indicating that these cells are the most resistant ones in the sominiferous tubules.

In the present investigation, vacuolated cytoplasm of spermatogonia, deteriorated cytoplasm of 1ry spermatocytes and destructed spermatids were demonstrated following 15 days of mancozeb treatment. It is well known that among Sertoli cells functions are the production of a fluid that acts as a nutritional for the developing spermatozoa and forming the testis barrier to protect the germ cells from blood-born noxious agents (Gartner and Hiatt, 1997). Thus, it is possible to suggest that the destruction and malformation of spermatozoa might be attributed, at least in part, to the disturbance in the functions of Sertoli cells caused by mancozeb treatment.

In the present work, destructed interstitial cells were observed in the testis of mancozebtreated rats probably as a result of the direct notorious impact of mancozeb on the testicular tissue. There is still enough evidence to suggest an indirect pathway that might have acted indirectly to cause these effects on the testis through mancozeb-induced injury of other components of the endocrine system. Proper thyroid hormone production and homeostasis are required for the development of the reproductive system on one hand and in maintaining its functions on the other hand. In this regard Siril et al., (2000) studied the effects of thyroid hormone on Leydig cell (LC) regeneration in the adult rat after ethane dimethyl sulphonate (EDS) treatment. They found that hypothyroidism inhibits Leydig cell regeneration and hyperthyroidism results in accelerated differentiation of more mesenchymal cells into LC. The work of Cad and Rio (2002) supports this assumption where they reported that mancozeb had a dual effect as a thyroid-hormone inhibitor and a disturber of the human reproduction.

In the present histological and ultrastructural studies, the testicular tissue revealed normal appearance after simulta-neous treatment with mancozeb and DDB. Conspicuous regenerative features in the cytoplasmic organelles and the nucleus were detected in the majority of the spermatogenic cells.

Moreover, the interstitial cells resumed their normal appearance. Hepatoprotective and regenerative functions were ascribed to DDB by several recent reports (Liu et al., 1995; Kim et al., 1999 \& 2000; Oh et al., 2000).

Liu et al., (1992) reported that treatment of male Sprague-Dawly rats with a daily intragastric dose of DDB, caused elevation of testosterone hydroxylation, and prom-oted the hepatic glutathione S-transferase induction, thereby promoting hepatic functions in biotransformation of steroid hormones as well 


\section{Manar Effat Selim}

as metabolization and elimination of xenobiotics.

The testis is the site for formation of the male sex hormones, testosterone and other similar androgenic steroids (Young, 1975). These hormones are produced by the Leydig cells. Testosterone is the principal hormone secreted by the Leydig cells and it is essential for the development of germinal epithelium within the seminiferons tubules, the maturation of gonadocytes to type A spermatogonia as well as the formation and maintaining of internal genitalia (Burkitt et al., 1995). In the present work, leyding cells resumed their normal construction, suggesting that DDB might have directly or indirectly affected testosterone secretion. DDB may have the ability for protection of Leydig cells from the mancozeb degenerative actions particularly on the DNA level. Moreover, DDB slows down the hepatic degradation of testosterone though formation of cytochrome $\mathrm{P}_{450}$ complex, thereby DDB inhibits testosterone 6 Beta hydroxylation activity, suggesting that DDB might play an indirect role in testicular function through inhibition of hepatic degradation pathway of testosterone (Kim et al., 2000; Ji Yeon et al., 2001; Back et al., 2001).

DDB has a high specificity for binding to several types of damaged DNA (Aleksey et al., 1996; Ann et al., 2000; Joanna et al., 2000; Mitsuo et al., 2001). Moreover, a possible interaction of DDB, through formation of a transduction complex involved in cell cycle regulation suggests an additional role for DDB in cellular repair. Therefore, DDB1 may in conjunction with other proteins, regulate cellular transcription process and control cell cycle progression after extensive DNA damage, (Wittschieben and Wood 2003). These authors reported that DDB2 is localized in both the nucleus and the cytoplasm, reflecting its role in recognized damaged DNA.

Thus, it is possible to suggest that in the present study, DDB might have ameliorated and amended the abnormalities caused by mancozeb through the protection of DNA and preserving the normal cellular functions. It is also possible that the protective properties of DDB were extended to extratesticular sites, i.e., through the protection of thyroid gland and the liver cells from mancozeb impacts. This would lead to restoration of the permissive action of thyroid hormones as androgen that can act more effectively in their presence. Hypothyroid animals usually manifest signs of hypogonadism and disrubted reproductive functions. Another explanation for DDB extratesticular effects might be through the improvement of hepatic androgen metabolizing process as a consequence of the amendment of hepatic impaired functions induced by mancozeb.

In conclusion chronic mancozeb toxicity led to impaired spermatogenesis and steroi-dogenesis. By using DDB simultane-ously with mancozeb, clear signs of tissue repair were evident. This ameliorating property exerted by DDB was probably a result of a direct action on the testis or due to extracellular effects.

So, it is advisable to supplement works or personals dealing with this fungicide by DDB to abate its toxic effects.

\section{References}

1. Aleksey, K., David, M., Anne, F., Nicholas, X. and Aziz, S. (1996): Functional complementation of Xeroderma Pigmentosum complementation group $\mathrm{E}$ by replication protein A in an in Vitro system, Proc. Nal. Acad., 93: 5014 - 5018.

2. Ann, F., Toshiki, I., Jay, A., Weiliu, L. and Masaru, Y. (2000): Human damage specific DNA- binding protein $\mathrm{P}_{48}$. J. Biol. Chem., 275(28): 21422 - 21428.

3. Back, M. S., Kim, J. Y., Yim, Y. H. and Kim, D. H. (2001): Metabolism of DDB by human liver microsomal $\mathrm{P}_{450}$, Drug Metab. Dispos., 29: 381 - 388.

4. Baligar, P.N. and Kaliwal, B. B. (2001): Induction of gonadal toxicity to female rats after chronic exposure to mancozeb. Ind. Health, 39(3): $235-243$.

5. Belpoggi, F.; Soffritti, M.; Guarino, M.; Lambertini, L.; Cevolani, D. and Malt, O.(2002): Results of long-term experimental studies on the carcinogenic effect of ethylene-bis-dithiocarbonate (Mancozeb) in rats.Ann.N.Y.Acad.Sci.,982(12) 123 - 136.

6. Bindali, B.B. and Kaliwal, BB. (2002): Anti-implantation effect of Carbamate fungicide mancozeb albino mice. Ind. Health, 40(2): 191 - 197.

7. Burkitt, H.; Young, B. and Heath, J. (1995): "Wheater's Functional Histology", $3^{\text {rd }}$ ed. Churchill Livingstone, London.

8. Cad,S. and Rio,J. (2002): On the rumors about the silent spring. Review of the scientific evidence linking occupational and environmental pesti-cide exposure to endocrine disruption health effects. Reproducao, Antitiroi-danos, Neoplasias, 18(2):379- 402.

9. Creasy,D.and Foster,P.(1991):Male Reproductive System. In: "Handbook of Toxicologic Pathology". (Haschek, W. M. and 
Rousseaux, C. G. eds.). Academic Press, London and New York. PP 829 - 874

10. Fejes,S.,Budai,P.;Varnagy,L.Molnar,T., Szabo,R.and Fanesi,T.(2002): Toxicity of a mancozeb containing fungicide formulation and sulphate to chicken embryos after administration as a single compound or in combination. Meded Rijksunv Gent Fak Landbouwkd Toegep Biol Wet.,67(2):105109.

11. Gartner,L.and Hiatt,J.(1997): "Histology". W. B. Saunders Company, U.S.A.

12. Indoki, T.; Yamagami, S.; Indoki, Y. and Endo, H. (2004): Human $\mathrm{DDB}_{2}$ splicing variants are dominant negative inhibitors of UV-damaged DNA repair. Biochem. Biophys. Res. Commun., 314(4): 1036 - 1043.

13. Ji-Yeon, K., Minsun, B., Sung, D. and Dong, K. (2001): Characterization of the selectivity and mechanism of cytochrome $\mathrm{P}_{450}$ inhibition by dimethylenedioxy biphenyl-dicarboxylate. Drug metabolism and disposition, 29(12): $1556-1559$.

14. Joanna, L.; Anna, C.; Joanna, R. and Piotr,W.(2000): Detection of damagerecognition proteins from human lymph-ocytes. Acta. Biochim., Polonia, 47(2): 443 - 450.

15. Junqueira, I.; Carneiro, J. and Kelley, R. (1998): "Basic Histology" $9^{\text {th }}$ ed. Appleton and Lange, U.S.A.

16. Kackar, R., Srivastava, M.K. and Raizada, R. B. (1999): Assessment of toxicological effects of mancozeb in male rats. Indian J. Exp. Biol., 37(6): 553 - 559.

17. Kim, S.; Kim, H.; Choi, S. and Ryu, J. (2000): Inhibition of lipopolysaccharideinduced 1-kappa B degradation and tumor necrosis factor-alpha expression by $5,66^{\circ}$ dimethylene dioxybiphenyl 2,2`dicarboxylate (DDB). Minor role in hepatic detoxifying enzymes expression. Liver, 20(4): $319-329$

18. Kim, S.; Kim, S.; Yim, H.; Lee, W.; Ham. K.; Kim, S.; Yoon, M. and Kim, Y. (1999): Effect of dimethyl-4,4-dimethoxy5,6,5 ‘, ‘-dimethylenedioxybiphenyl-2,2`dicarboxy-late (DDB) on chemicallyinduced liver injury. Boil. Pharm. Bull., 22(1): 93 - 95.

19. Liu, P.; Kawada, N.; Mizoguchi, Y. and Morisawa, N. (1992): Arachidonate metab- olism in D-galactosamine-or $\mathrm{CCl}_{4}$-induced acute and chronic liver injuries in rats. Gastroenterol. Jpn., 27(5): $642-631$.

20. Liu, T.; Hwua, Y.; Chao, T. and Chi, C. (1995): Mechanistic study of the inhibition of aflatoxin $\mathrm{B}_{1}$-induced hepatotoxicity by dimethyl 4,4-dimethoxy-5,6,5 '6 -dimethylene dioxybiphenyl-2, 2-dicarboxylate. Cancer Lett., 89(2): 201 - 205.

21. Mitsuo, W., Aki, K., Hiroshi, M., Aziz, S., Toshio, M. and Osama, N. (2001): DDB Accumulates at DNA damage sites immediately after UV irradiation and directly stimulates Nucleotide Excision repair. J. Biol. Chem., 277(3): 1637 - 1640.

22. Oh, S., Lee, C. and Ku, Y. (2000): Pharmacokinetics and hepatoprotective effects of 2-methylaminoethyl-4,4-dimethoxy-5,6,5 ,6 -dimethyl-enedioxy iphenyl 1-2-carboxylic acid-2 -earboxylate monohyd- rochloride in rats with $\mathrm{CCl}_{4}$-induced acute hepatic failure. Pharm. Pharmacol., 52(9): 1099 - 1103.

23. Siril, H., Nathaniel, M., Jan, M. and Chamidrani,S.(2000):Effects of thyroid hormone on Leydig cell regeneration in the adult rat following Ethane Dimethane Sulphonate treatment. Biol. Reprod., 63:11151123.

24. Tomasi, T. E., Ashcraft, J. and Britzke, E. (2001): Effects of fungicides on thyroid function, metabolism, and thermregulation in cotton rats. Environ. Toxicol. Chem., 20(8): 1709 - 1715.

25. Varnagy, L.; Budai, P.; Molnar, E.; Takacs, I. and Gejes, S. (2001): One-generation reproduction toxicity study of mancozeb and acetate. Meded Rijksuniv. Gent Fak. Landbouwkd Toegep. Biol. Wet., 66(26): $873-878$.

26. Weiliu, L., Anne, F., Jay, A., Rachel, D., Alex, A. and Sturart, L. (2000): Nuclear transport of human DDB protein induced by ultraviolet light. J. Biol. Chem., 275(28): $21429-21434$

27. Wittschieben, B. and Wood, R. (2003): DDB complexities. DNA repair ANNST, 2(9): 1065 - 1069.

28. Young, J. Z. (1975): "The life of Mammals: Their Anatomy and physiology". $2^{\text {nd }}$ ed. Oxford University Press. 


\section{Manar Effat Selim}

\section{التأثير المحسن المحتمل للدايميثيل دايكربوكسيلات بيفينيل (ددب) ضد الهد تسمم الخصية المحدث في الجرذان بواسطة المانكوزيب دائركب}

\section{منار عقت سليم}

\section{قسم علم الحيوان- كلية العلوم- جامعة عين شمس}

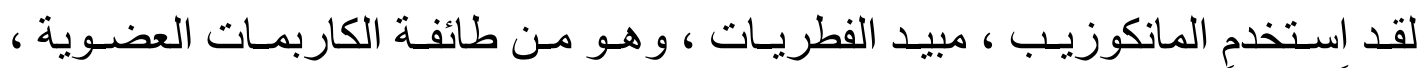

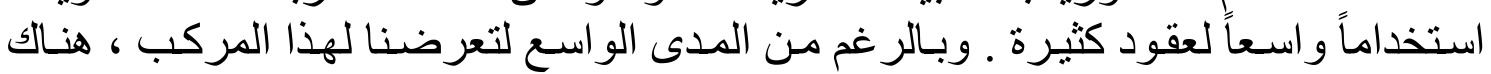

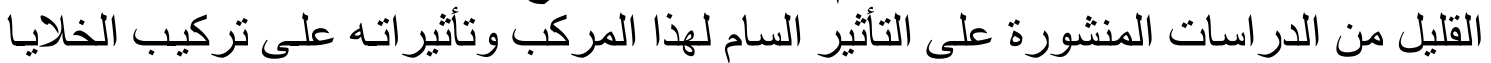

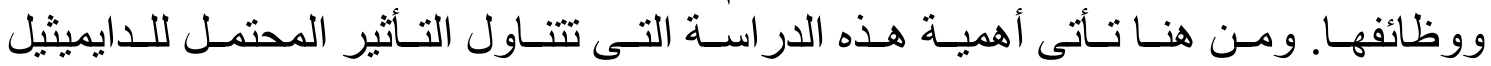
دايكربوكسيلات بيفينيل ( ددب ) لتقليل المخاطر التى يسببها هذا المركب هـ على الخصيتين.

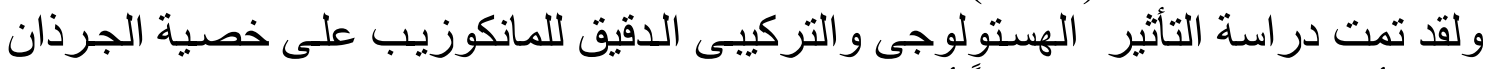

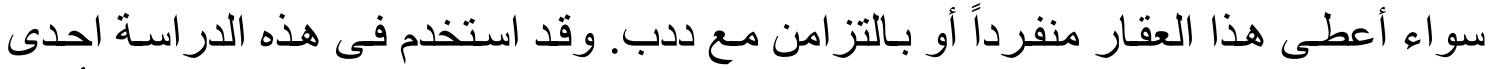

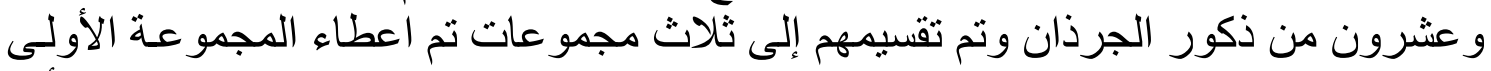

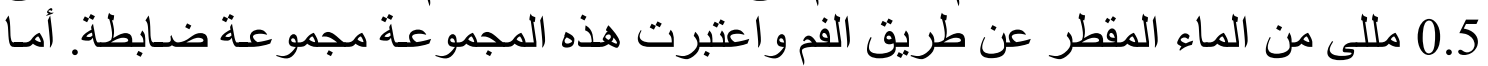

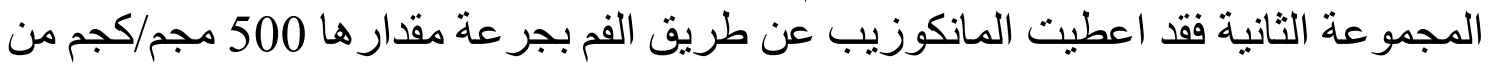

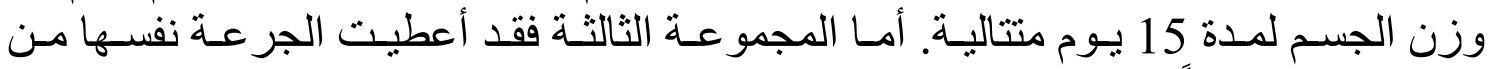

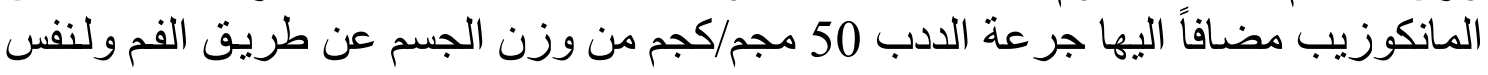
المدة.

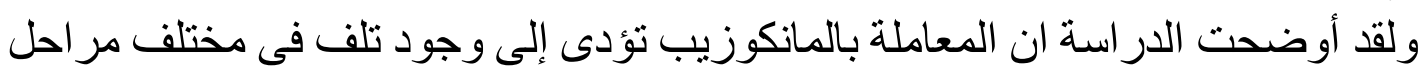

تكوين الحيو انات المنوية وفى الخلايا البينية.

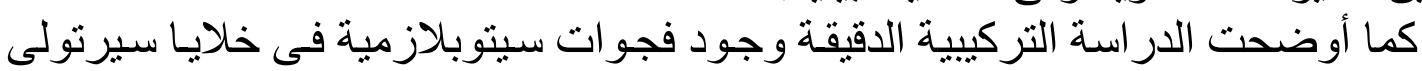

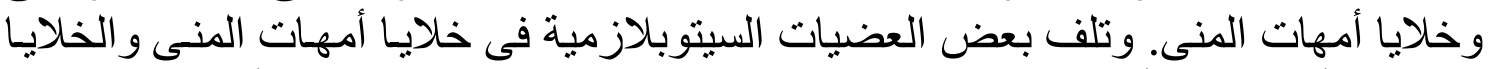
المنوية الأبندائية. بالأضافة إلى التدمير الواضئ اضلح للطلائع المنوية فى معظم الأنيبيبات المنوية.

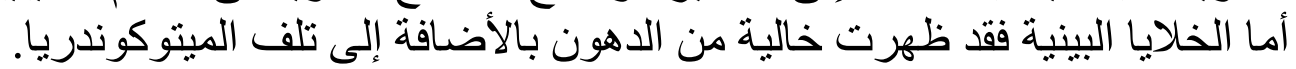

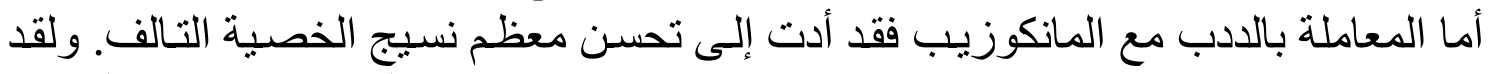

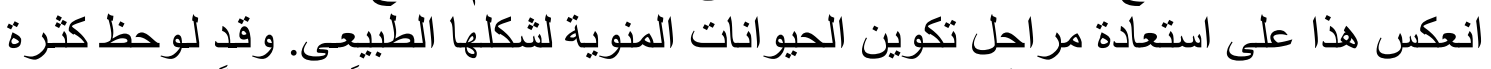

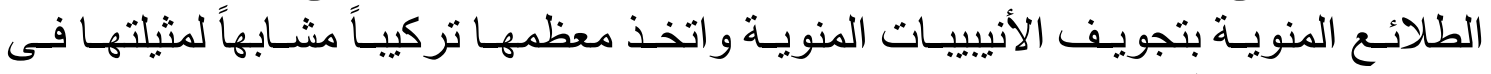
المجمو عة الضابطة. و على ذلك ، فقد تبين من هذا البحث ان للدددب المقدرة على تحسين التأثنير ات الضـارة المحدثة بالمانكوزيب. 